\section{Australia delays carbon reduction scheme}

The Australian government has delayed its proposed cap-and-trade scheme for regulating greenhouse-gas emissions (see Nature 458, 554-555; 2009).

Prime Minister Kevin Rudd announced on 4 May that, in order to "manage the impacts of the global recession", the system will be phased in from 1 July 2011, a year later than planned. Until July 2012, permits to emit carbon dioxide will be sold at a fixed price of Aus\$10 (US\$7.5) per tonne, and companies involved will be able to buy an unlimited number of them.

Rudd said he hopes to push the necessary legislation through parliament this year. He will also revise the upper limit on Australia's emissions-reduction target to $25 \%$ below 2000 levels by 2020 , up from $15 \%$, depending on agreements reached at December's UN summit in Copenhagen.

\section{Data 'mishandling' stalls Down's syndrome test}

Research data supporting a non-invasive prenatal screen for Down's syndrome were "mishandled" and cannot be relied on, according to the biotechnology company that has been developing the test.

On 29 April Harry Stylli, chief executive of Sequenom in San Diego, California, said that four employees suspected of mishandling data had been suspended. An independent committee is investigating the matter. Investors have since filed several class-action lawsuits against the company.

Sequenom's tests rely on examining minute amounts of fetal DNA or RNA circulating in maternal blood. The hope is to provide an alternative to more invasive methods such as amniocentesis, which carry a small risk of miscarriage. The company intends to complete a new clinical validation of its assays by the end of the year, but will not file for regulatory approval until two larger clinical trials are completed in 2010.

\section{Misconduct scandal hits German university}

Sixteen members of a Collaborative Research Centre (SFB) at the elite University of Göttingen, funded by Germany's major national research agency, the DFG, are being investigated for scientific misconduct.

SFBs are highly prized and generously funded awards that continue for up to 12 years. In a statement on 4 May, the university said that an internal preliminary investigation had found that the scientists listed non-existent papers in their routine

\title{
Obama revokes endangered species rule
}

President Barack Obama

last week revoked a rule

that limited the role of

wildlife experts in reviewing

roads, pipelines and

other projects under the

Endangered Species Act.

The rule, established in

the last weeks of George W.

Bush's administration,

allowed federal agencies

planning such projects

to make decisions about

whether threatened or

endangered species would

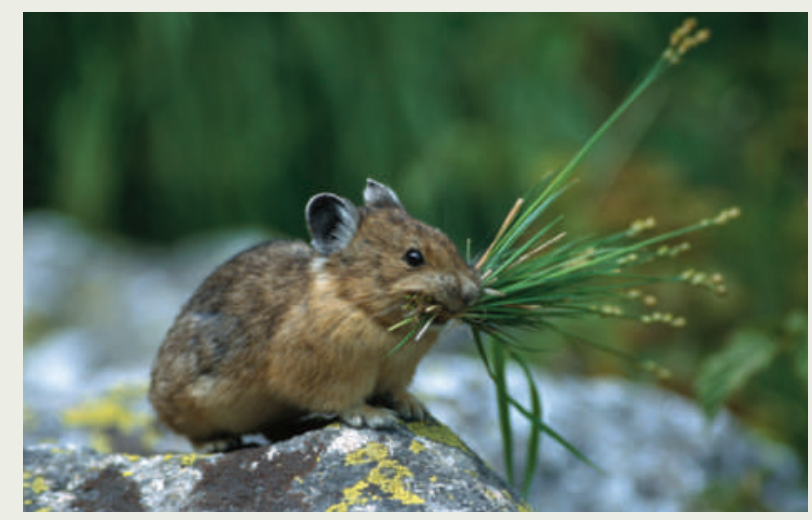

be harmed, without first

consulting the National Marine Fisheries Service or the Fish and Wildlife Service. Among species currently being considered by the Fish and Wildlife Service for protection under the Endangered Species Act is the American pika (pictured).

The Bush administration said that the change reduced unnecessary paperwork, but environmentalists said that it undermined a key safeguard.

Obama had promised to review the issue in early March, and the Department of the Interior followed up by rescinding the rule on 28 April.

milestone report for continuation of funding. The researchers have apologized to the DFG for providing false information.

The interdisciplinary project, studying the stability of the Indonesian rainforest, had been approved $€ 16.6$ million (US\$22.3 million) from 2000 to June this year. A request for a further $€ 8.6$ million has been withdrawn. The DFG is looking into the case and investigating whether financial irregularities occurred.

\section{South Korea re-enters human stem-cell research}

On 29 April, South Korea's national bioethics committee conditionally approved a study using human eggs for stem-cell studies - the first such licence granted since a scandal unfolded over similar work by Korean researcher Woo Suk Hwang.

A team at Cha General Hospital in Seoul will be permitted to create cloned human embryos using the eggs. The study's go ahead is dependent on four conditions: donors must give informed consent; research with human eggs should be

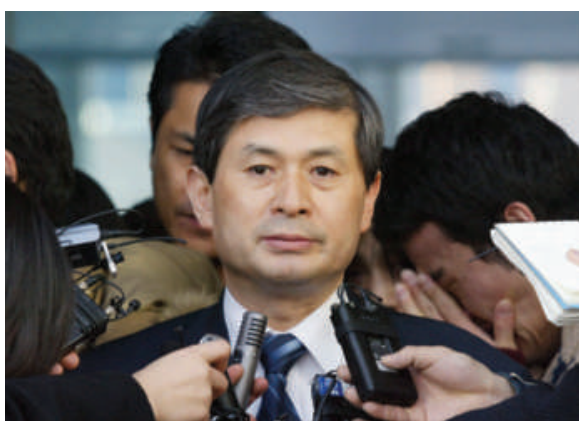

Woo Suk Hwang: still on trial for stem-cell fraud. minimized; an internal review board must oversee the experiments; and the study cannot be hyped by mention of possible clinical benefit.

The research aims to establish stem-cell lines from the cloned embryos, for research and potentially for therapy. Hwang published claims to have done that in 2005, but in January 2006 his research was found to be fraudulent and his acquisition of human eggs unethical. He remains on trial for fraud, embezzlement and violation of the nation's bioethics law.

\section{Biosecurity report cautious on strict researcher vetting}

Academic researchers working with dangerous pathogens should not be subjected to the same stringent background checks currently required for scientists working in chemical and nuclear weapons programmes, a panel of US government advisers recommended last week.

The National Science Advisory Board for Biosecurity report, released on 29 April, examined how to reduce "insider threats" posed by bioscientists with malicious intent. It noted that security regulations governing bioscientists were bolstered after the US anthrax attacks of 2001, and said they should continue to be strengthened.

But piling on "onerous" requirements, it said, could cause the best scientists to shun important work with pathogens and could isolate those that remain in the field.

A working group, established by former president George W. Bush in January, is reviewing US lab biosecurity and is expected to report in July. 